
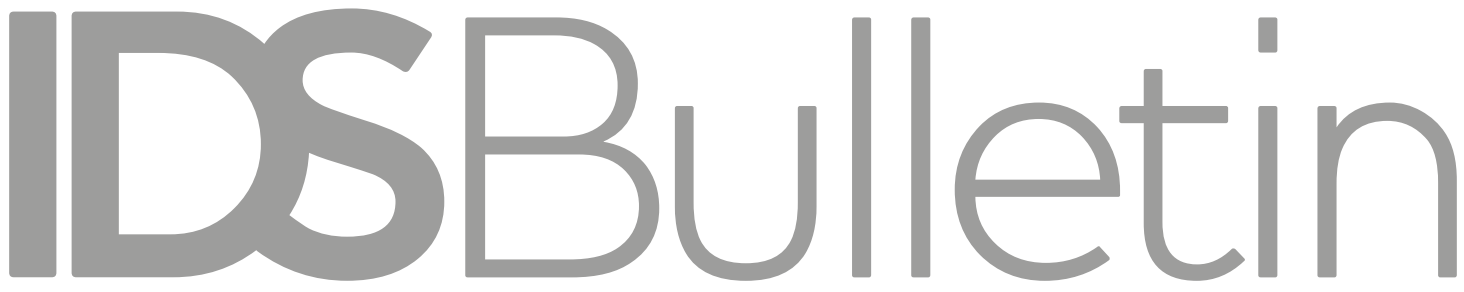

Transforming Development Knouledge

Volume 49 | Number 5 | November 2018

\title{
YOUTH EMPLOYMENT AND THE \\ PRIVATE SECTOR IN AFRICA
}

Editors Seife Ayele, Dominic Glover and Marjoke Oosterom

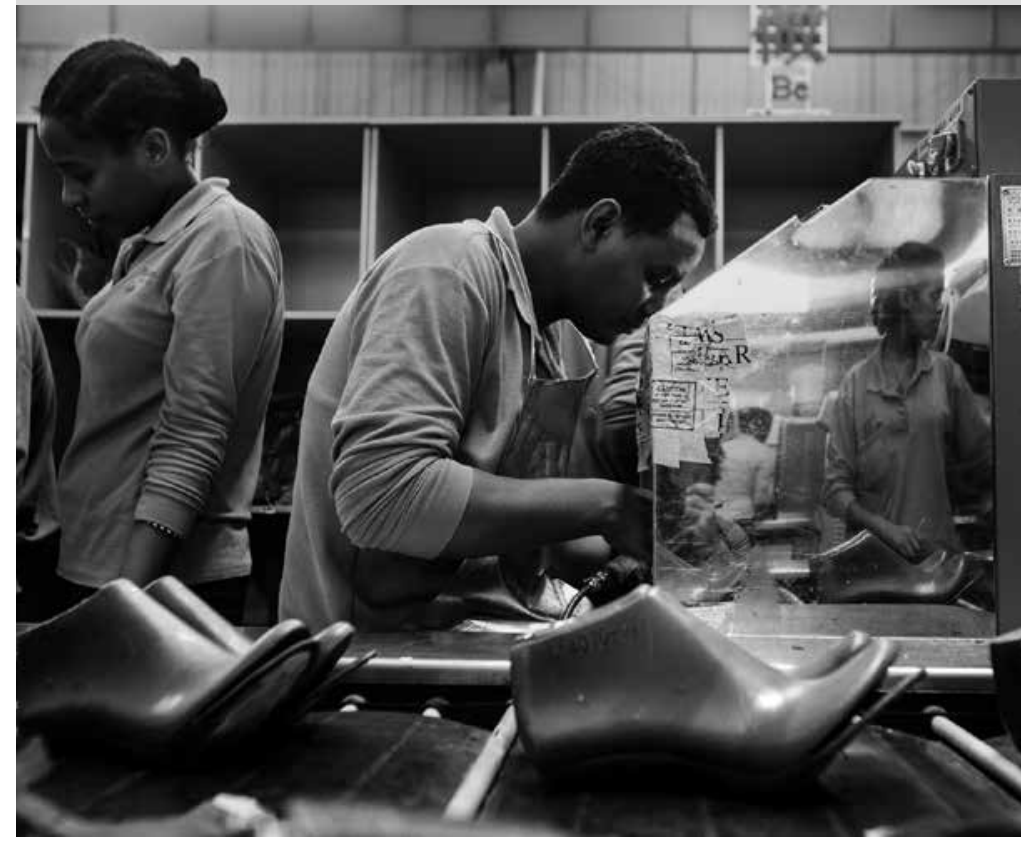


Notes on Contributors

Clementina Oluwafunke Ajayi In Memoriam vii

Introduction: Youth Employment and the Private Sector in Africa

Seife Ayele, Marjoke Oosterom and Dominic Glover

Ethiopia's Agricultural Transformation: Agribusiness' Contribution to Reducing Youth Unemployment

Tesfamicheal Wossen and Seife Ayele

Labour Casualisation and Youth Employment in Ghana's Formal Private Sector Gertrude Dzifa Torvikey

\section{Uganda's National Youth Policy and Job Creation for Youth}

Rita Makumbi

Skills Gaps and Mismatches: Private Sector Expectations of Engineering Graduates in Ethiopia

Jerusalem Yibeltal Yizengaw

Fostering Agribusiness Entrepreneurship for Kenyan Youth through Practice-Based Education

John Muchira

Navigating Precarious Livelihoods: Youth in the SME Sector in Zimbabwe

Simbarashe Gukurume

Assessing the Effectiveness of Employment Programmes for Ex-Combatants:

A Case Study of Nigeria's Post Amnesty Programme (PAP)

Tarila Marclint Ebiede

Clossary 


\title{
Uganda's National Youth Policy and Job Creation for Youth"
}

\author{
Rita Makumbi ${ }^{1}$
}

\begin{abstract}
Uganda's Youth Livelihood Programme (YLP) and the consequent Youth Livelihood Fund (YLF) are government programmes established under the National Youth Policy (NYP), designed to support young people to find employment by extending grants and other support to small groups of young entrepreneurs, to help them to start small businesses and thus create employment for other young jobseekers. Drawing on a study involving 177 rural and urban youths, this article discusses the design and implementation of the YLP. It argues that the NYP has fallen short in several respects. In addition to funding, employment generation requires additional support for youth in a range of areas, including awareness-raising about employment opportunities, enhancing vocational and entrepreneurial skills, and providing advice and guidance on starting up small businesses.
\end{abstract}

Keywords: youth employment, Africa, Uganda, National Youth Policy, value addition.

\section{Introduction}

Like other countries in Africa, Uganda faces the challenge of generating economic growth and providing employment for youths. Youths make up a third of the global population (World Bank 2015) and Africa and Asia share high dependency ratios of people younger than 15 and older than 64 (Kilimani 2017). Moreover, Africa has the world's youngest population and accounts for close to half of the entire world's unemployed youth (Atinc et al. 2005). A youth in Uganda is a person who is aged 18-30 years (UBOS 2017), and the Ugandan Bureau of Statistics (UBOS) for 2015 shows that while 74.5 per cent of the youth were employed, the remaining 25.5 per cent were either unemployed (4.9 per cent) or inactive (20.6 per cent) (UBOS 2015). Research also shows that approximately 400,000 Ugandan youths enter the job market annually to compete for approximately 9,000 available jobs (Magelah and Ntambirweki-Karugonjo 2014). Urban youth are more likely to be unemployed than rural youth, and young women are twice as likely to be unemployed as young men (Ahaibwe and Mbowa 2014). The prevalent unemployment and underemployment could be a source 
of many social, economic, and fiscal problems in the future, placing a heavy burden on public revenues (Makumbi 2018).

The Ugandan government has adopted a number of policies and initiatives that are intended to address the youth employment challenge. Among the most important is the National Youth Policy (NYP), which was adopted in 2001. The NYP has focused on agriculture and associated industries (Republic of Uganda 2001), because that sector has been the main source of livelihood for Ugandans. Out of a national population of approximately 41 million people, 83.2 per cent live in rural areas (Aghasili 2015). Uganda also has a large agricultural economy which contributes more than 20 per cent of the gross domestic product (GDP) growth (Dalipagic and Elepu 2014). Small-scale agriculture is a major source of employment (Diao 2010), and several analysts still agree that commercial food crops have the potential to generate economic opportunities (Kumar and Kalita 2017; Ranum, Peña-Rosas and Garcia-Casal 2014; Nabbumba and Bahiigwa 2003).

The Government of Uganda has identified private enterprise development as a critical strategy for economic growth and job creation in the country (Vision Reporter 2018). In 1995, the government established the Private Sector Foundation Uganda (PSFU) to oversee the growth of the private sector. The role of PSFU involves encouraging an environment that allows creation of jobs, generation of revenue, and enhancement of exports. The PSFU is continuously challenged to look out for new opportunities in the private sector so as to be able to match the dynamics in the economy (ibid.).

The Youth Livelihood Programme (YLP) and Youth Livelihood Fund (YLF) were created as vehicles for the promotion of youth enterprise development, through the provision of entrepreneurship training, information services, and microcredit facilities to the youth. Support for micro projects was informed by a policy consensus that funding for small enterprises could drive job creation and stimulate economic growth (Reeg 2015; Edquist 2011; Karnani 2007). However, a decade and a half after the NYP was inaugurated, the youth unemployment and underemployment situation remains a pressing problem.

Drawing on a study involving 177 rural and urban youths, this article discusses the design and implementation of the YLP. It argues that the NYP has fallen short in several respects. In addition to funding, employment generation requires additional support for youth in a range of areas, including awareness-raising about employment opportunities, enhancing vocational and entrepreneurial skills, and providing advice and guidance on starting up small businesses. To help focus the analysis, the article concentrates particularly on data relating to job creation and youth-led enterprises within the maize value chain in Uganda. Agricultural value chains have been identified as an important source of employment for large numbers of young people (Brooks et al. 2013). Analysts believe that the maize value chain could generate many jobs 
for youths, if they are assisted to engage in value-adding activities (Adesugba and Mavrotas 2016; Kluve 2016).

The rest of the article is organised as follows: Section 2 reviews the NYP and its core elements, the YLP and the YLF. While Section 3 outlines data sources, Section 4 presents the analysis and discussion of data. Section 5 concludes with implications for youth employment policy.

\section{Uganda's National Youth Policy, Youth Livelihood Programme, and Youth Livelihood Fund}

Uganda adopted the NYP in 2001, with the specific goal of enhancing the economic contributions of youth. The policy was a reaction to worsening youth conditions, where an increase in rural to urban youth migration was not accompanied by job creation. A growing number of the youth were dropping out of school, and there was a lack of government funding to support them. The YLP and YLF were created to provide funding and other support to small enterprises led by youth. The aim was not only to support small business development, but also job creation (Republic of Uganda 2001; Makumbi 2018).

The Government of Uganda allocated UGX 265 billion (US\$71.42 million) to the YLP/YLF for the period 2014-18. The funds were assigned to support youth-led small enterprise development in different sectors, to include grain-milling, metal fabrication, clay products, carpentry, bakery, tailoring, soap-making, the manufacture of fuel briquettes, fishing, poultry production, arts and crafts, music and drama, and beauty. To apply for support from the YLP/YLF, youths were invited to form small groups, known as youth interest groups (YIGs) and to complete a project interest form (PIF) (Makumbi 2018).

In 2017, it was reported that the YLF had disbursed US\$17.38 million, representing only 24 per cent of the approved budget, at an average rate of approximately US\$620,000 every month. However, in January 2017, the government suspended the disbursement of YLF loans, because the Fund was experiencing a large shortfall in the expected repayments. The YLF was designed as a revolving fund, so that the capacity to make new loans was dependent upon the receipt of timely loan repayments from existing recipients. However, repayments were running far behind expectations; for example, recipients in Kampala had paid back only US\$61,641, leaving US\$138,464 outstanding. In Mukono District, US $\$ 10,740$ had been repaid, but US\$56,021 was still outstanding (Semakula and Kashaka 2017).

Nonetheless, at the time the YLF was suspended, it was claimed that it had supported the creation of 114,471 jobs for youth over the preceding three years (Table 1). The agricultural sector had received the largest share of YLF loans, amounting to US\$7.41 million or 42.7 per cent. Thus, 43 per cent of the reported new jobs were in the agricultural sector and a further 3 per cent in agro-industry. Trade and services also represented substantial shares of the jobs that were said to have been created (30 per cent and 10 per cent, respectively). 


\begin{tabular}{llcc} 
Table 1 Jobs created under the National Youth Policy, 2014-17 & \\
\hline \multicolumn{1}{l}{ Sector } & $\begin{array}{c}\text { Number of jobs } \\
\text { created }\end{array}$ & Percentage \\
\hline 1 & Agriculture & 49,695 & 43 \\
\hline 2 & Trade & 33,771 & 30 \\
\hline 3 & Services & 11,979 & 10 \\
\hline 4 & Industry & 7,028 & 6 \\
\hline 5 & Vocational skills & 6,071 & 5 \\
\hline 6 & Agro-industry & 3,981 & 3 \\
\hline 7 & Agro-forestry & 1,180 & 1 \\
\hline 8 & Information Communication Technology & 625 & $<1$ \\
\hline 9 & Creative industry & 137 & $<1$ \\
\hline Total & & 114,467 & 100 \\
\hline
\end{tabular}

Source Makumbi (2018).

\section{Data sources}

This article draws upon data generated as part of a doctoral study into youth employment and job creation in Uganda (Makumbi 2018). A survey was carried out with 177 respondents, 43 per cent female and 57 per cent male, as well as focus group discussions (FGDs) and interviews with key informants. The participants in the research were YLF funded recipients involved in youth-led micro projects at various stages of the maize value chain, in both urban and rural areas (the city of Kampala and Mukono District). In total, 21 individual interviews and seven FGDs were conducted. The survey was conducted in 2017 (ibid.).

\section{Analysis and discussion of data}

Some descriptive statistics about the survey respondents are presented in Table 2. The majority of respondents (51 per cent) defined themselves as maize growers, and identified this as their major source of livelihood within the maize value chain. Many of the youths in this category were unaware of other value-adding activities within the maize processing chain, including aspects such as livestock feed production. Twenty-one per cent of the respondents identified themselves as transporters, who conveyed maize grain from the production villages to central storage places or from villages to bigger towns and the city of Kampala. The remaining youths (about 28 per cent) were working as grain processors, livestock feed producers, etc. Among the survey respondents, rural youths were typically maize producers and were often also involved in non-farm livelihood activities, such as small- and medium-scale maize processing and livestock feed production and distribution. In Mukono District, 79 projects were implemented under the YLP, of which more than half (53 per cent) were in the agricultural sector, usually in 


\begin{tabular}{llc}
\hline & Sector & $\begin{array}{c}\text { Youth } \\
\text { participants in } \\
\text { the survey }\end{array}$ \\
\hline 1 & Maize growers & 91 \\
\hline 2 & Transporters & 37 \\
\hline $3 \quad$ Agro-processors, distributors, seedling sales, livestock feed, etc. & 49 \\
\hline \multicolumn{2}{l}{ Total } & 177 \\
\hline Source Makumbi (2018). & \\
\hline
\end{tabular}

businesses with less need for high-level skills. Urban youths were more likely to be involved in (local) transport, processing, and marketing activities. In Kampala, the agriculture-related trade sector was where most projects were implemented.

\subsection{Problems in the YLP/YLF}

A number of key flaws have come to light, which undermined the effectiveness and impact of the YLP/YLF as a programme for enterprise development and job creation. Major problems related to the insufficient quality and detail of the business proposals submitted to the programme and awarded funds. For example, a majority of the project proposals prepared by the YIGs, including those represented in all six of the FGDs carried out for this study in Kampala and Mukono District, failed to take loan interest into account, as it was assumed by both the youths and the government that repayment of the loan would be completed within one year, and would not be subject to repayment interest. In reality, repayments typically continued beyond the first year, when they would be subject to interest at 5 per cent, but most of the fledgling entrepreneurs had not budgeted for the interest on their YLF loan. The programme finances were therefore subject to different cash flows than had been projected (Makumbi 2018).

Another problem related to the disbursement schedule. According to our interviews, many of the YIGs expected a one-time disbursement; however, the disbursements were made in tranches, as a method of controlling the programme. As some projects developed more slowly than expected, while others stalled, late claims for additional funding, and failures to claim previously allocated funds, disrupted the disbursement and repayment schedules (ibid.).

There were also problems of external monitoring of loan recipients' performance by the YLP/YLF administration. The loan recipients were supposed to submit a financial and operational report, using a prepared format, at least annually. However, in 48 per cent of cases, this was not done. The YIGs were also required to submit a justification and seek approval for any significant changes in their business plans. Such changes could be common; however, a minority ( 45 per cent) of affected businesses 
complied with this rule. The YLP/YLF was also subject to problems of fraud and bad faith. Some YIG leaders disappeared with the funds, leaving the remainder of the group with an uncertain future; in most cases, this meant that projects were not fully realised (ibid.).

The problems of budgeting and financial management within the YLP/YLF stemmed from weaknesses in the design and implementation of the small business projects proposed by applicants to the scheme. The YLP/YLF placed the responsibility on the YIGs to conceive and design viable business proposals, such as clear value propositions, goals, targets, activities, management plans, financial indicators, and monitoring systems. The quality and detail of the proposals submitted by the YIGs were often insufficient, and the youths were inexperienced. Fifty-nine per cent of the youths interviewed for this study felt that the guidance they had been given was inadequate to start and grow successful businesses (ibid.).

The budgets presented by the YIGs often neglected to take into account the effects of high inflation between the time of application and the time of loan approval and the first disbursement of funds. Groups we interviewed explained that they had applied for funds in 2014 but had not received the money until 2015, by which time the prices of some key business inputs had increased significantly. In general, inflation was problematic for all the new businesses. Inflation in Uganda leads to high operating costs, reducing business savings considerably. For example, one participant in the Bajjo Charcoal Briquette project, which received support from the YLP/YLF, complained that continual price increases on raw materials created a disincentive to add another value-adding activity into their existing business model (ibid.). ${ }^{2}$

In some cases, YIGs failed to include their basic cost-of-living expenses in their business budgets. Since at first they had no other source of income other than the YLF loan, they had to live off the project funds during the first period of investment, when the funds should have been used to invest in the new business. This was particularly problematic in view of the very small micro-loans awarded in many cases. The distribution of US\$17.38 million to 114,471 youths represented a modest pay-out of only US\$152 per recipient. This raises questions about the YLP/YLF ambition to generate adequate incomes for the loan recipients themselves, and to generate additional employment opportunities in new business enterprises, at the same time (ibid.).

Some survey respondents and key informants evidently had not perceived their business enterprises as 'projects', as such, with defined goals and timescales. Instead, many participants in YIGs perceived their YLF loans merely as a kind of subsidy or grant to support their income-generating activities in general and their cost of living (ibid.).

As well as insufficient training and guidance in business and financial management, many YIGs also complained about the inadequacy of 
the technical training that was offered by the programme. For example, youth leaders in Kampala indicated that their knowledge about quality control, storage, and processing of maize grain was narrow. This shortfall in capabilities enabled predatory middlemen within the value chain to take advantage of fledgling enterprises, imposing additional costs on their operations (ibid.).

Some informants complained about a general lack of information and advice that could help raise awareness of business opportunities, as well as the capability to engage with them. For example, one youth leader referred to the business of making fuel briquettes from dried maize cobs. Briquette-making is an enterprise found in both rural and urban areas, with varying levels of expertise. The youth leader told us, 'This briquette business has potential to grow if there was awareness among potential users who are more familiar with [conventional] charcoal.'

According to a quantitative analysis carried out by Makumbi (2018), the YLP/YLF had a small but positive impact on job creation. Eighty-one per cent of youths surveyed in Kampala and Mukono District agreed that well-supervised projects had the potential to generate jobs; however, the problems discussed above created obstacles to this outcome.

Nineteen per cent were sceptical about the potential for job creation through small- and micro-enterprise development. Almost 13 per cent of the youths interviewed reported that they were unable to compete for jobs due simply to an excess in the supply of labour. This was common among boda (motorbike transporters), who are concentrated in urban areas. The FGD in the Rubaga and Kawempe divisions in Kampala revealed that those youth fortunate to be employed resorted to working late into the night. Others resigned themselves to staying idle until an opportunity appeared.

Despite the public investment through the YLP/YLF to support small enterprise development and private sector employment, some respondents, particularly educated youths, continued to regard the public sector rather than the private sector as the ideal source of employment, and declined to take work in the private sector. Some analysts, such as Holt (2012), have blamed negative attitudes among youth for their continued unemployment. Nonetheless, many of the barriers to employment were structural, especially lack of knowledge and inadequate information flows, which shaped perceptions and created obstacles to full participation of youth in employment. This insight reflects the finding by Ukachukwu (2014), that inadequate access to information contributes to the persistence of youth unemployment.

\section{Conclusion and recommendations}

The NYP endeavours to provide strategies for youth employment in the private sector. However, the reported study (Makumbi 2018) found that the majority of the youth were involved in relatively low-skilled labour activities, such as maize production and transportation. The study also identified a number of problems in the design and implementation of 
the YLP/YLF programme, thus hindering the successful launch and expansion of viable small- and micro-enterprises that could generate employment for rural and urban youth. Launching a successful business involves sophisticated skills of project planning and financial management, which are areas where youths may need support. This support would be additional to the technical advice and guidance needed to help youths engage in specific business sectors, such as the maize value chain.

The majority of youth-led enterprises supported by the YLP/ YLF remain engaged only at the lowest levels of the maize value chain, where the potential for value addition, and therefore viable income generation and job creation, is minimal. Going forward, the NYP should be more proactive in identifying potential employment opportunities for higher skilled workers within the maize value chain, and provide resources that would enable participation therein. In addition to funding, the NYP should support youth by raising awareness levels about employment opportunities, enhancing vocational and entrepreneurial skills, and providing advice and guidance on business opportunities and market linkages. The maize value chain as a whole also remains undeveloped, comprising only a limited part of the value-adding agribusiness industry in Uganda. Supportive government policies should help to develop the maize value chain in the country.

\section{Notes}

* This issue of the IDS Bulletin was produced in partnership with Mastercard Foundation.

1 Ndejje University, Kampala, Uganda.

2 Personal interview with YLP fund recipient, December 2016.

3 Personal interview, November 2016.

\section{References}

Adesugba, M.A. and Mavrotas, G. (2016) Delving Deeper into the Agricultural Transformation and Youth Employment Nexus: The Nigerian Case, NSSP Working Paper 31, Washington DC: International Food Policy Research Institute (IFPRI), www.ifpri.org/publication/delvingdeeper-agricultural-transformation-and-youth-employment-nexusnigerian-case (accessed 15 October 2018)

Aghasili, O.U. (2015) 'Fuel Choice, Acute Respiratory Infection and Child Growth in Uganda', Open Access Theses 564, West Lafayette IN: Purdue University, ProQuest Dissertations Publishing, https://docs.lib.purdue.edu/open_access_theses/564/ (accessed 15 October 2018)

Ahaibwe, G. and Mbowa, S. (2014) Youth Unemployment Challenge in Uganda and the Role of Employment Polices in Fobs Creation, Africa in Focus blog, 26 August, www.brookings.edu/blog/africa-in-focus/2014/08/26/ youth-unemployment-challenge-in-uganda-and-the-role-ofemployment-policies-in-jobs-creation/ (accessed 15 October 2018)

Atinc, T.M. et al. (2005) World Development Report 2006: Equity and Development, Washington DC: World Bank, http://documents.worldbank.org/curated/en/435331468127174418/ 
World-development-report-2006-equity-and-development (accessed 15 October 2018)

Brooks, K.; Zorya, S.; Gautam, A. and Goyal, A. (2013) Agriculture as a Sector of Opportunity for Young People in Africa, Policy Research Working Paper 6473, Washington DC: World Bank, https://openknowledge. worldbank.org/handle/10986/15605 (accessed 15 October 2018)

Dalipagic, I. and Elepu, G. (2014) Agricultural Value Chain Analysis in Northern Uganda: Maize, Rice, Groundnuts, Sunflower and Sesame, Kampala: Action Against Hunger | ACF International, www.actionagainsthunger.org/sites/default/files/publications/ Agricultural_value_chain_in_Northern_Uganda_Maize_rice_ groundnuts_sunflower_and_sesame_03.2014.pdf (accessed 15 October 2018)

Diao, X. (2010) Economic Importance of Agriculture for Sustainable Development and Poverty Reduction: Findings from a Case Study of Ghana, Policies for Agricultural Development, Poverty Reduction and Food Security, Paris: Organisation for Economic Co-operation and Development (OECD), www.oecd.org/agriculture/agricultural-policies/46341169.pdf (accessed 15 October 2018)

Edquist, C. (2011) 'Systems of Innovation: Perspectives and Challenges', African Fournal of Science, Technology, Innovation and Development 2.3: 14-43

Holt, A. (2012) 'Negative Attitude of Young People are Closing Doors to Jobs Says Survey', Charity Times, 17 May, www.charitytimes.com/ ct/negative_attitudes_young_people_are_closing_doors_to_jobs_ says_survey.php \%20.php (accessed 15 October 2018)

Karnani, A. (2007) 'Microfinance Misses its Mark', Stanford Social Innovation Review, https://ssir.org/articles/entry/microfinance_ misses_its_mark\# (accessed 15 October 2018)

Kilimani, N. (2017) 'Youth Employment in Developing Economies: Evidence on Policies and Interventions', IDS Bulletin 48.3: 13-32, http://opendocs.ids.ac.uk/opendocs/handle/123456789/12987 (accessed 28 June 2018)

Kluve, J. (2016) A Review of the Effectiveness of Active Labour Market Programmes with a Focus on Latin America and the Caribbean, Research Department Working Paper 9, Geneva: International Labour Office Kumar, D. and Kalita, P. (2017) 'Reducing Postharvest Losses during Storage of Grain Crops to Strengthen Food Security in Developing Countries', Foods 6.1: 8

Magelah, P. and Ntambirweki-Karugonjo, B. (2014) Youth Unemployment and Fob Creation in Uganda: Opportunities and Challenges, Infosheet 26, Kampala: Advocates Coalition for Development and Environment (ACODE), www.acode-u.org/Files/Publications/infosheet_26.pdf (accessed 15 October 2018)

Makumbi, B.R. (2018) 'The National Youth Policy and Job Creation in Uganda', unpublished $\mathrm{PhD}$ thesis, School of Business Administration, Nkumba University

Nabbumba, R. and Bahiigwa, G. (2003) Agricultural Productivity Constraints in Uganda: Implications for Investment, Research Series 151127, Kampala: Economic Policy Research Centre (EPRG), 
https://ideas.repec.org/p/ags/eprcrs/151127.html (accessed 15 October 2018)

Ranum, P.; Peña-Rosas, J.P. and Garcia-Casal, M.N. (2014) 'Global Maize Production, Utilisation and Consumption', Annals of the New York Academy of Sciences 1312.1: 105-12

Reeg, G. (2015) Micro and Small Enterprises as Drivers for Fob Creation and Decent Work, Discussion Paper 10/2015, Bonn: German Development Institute

Republic of Uganda (2001) The National Youth Policy: A Vision for Youth in the 21st Century, Kampala: Ministry of Gender, Labour and Social Development, www.youthpolicy.org/national/Uganda_2001_ National_Youth_Policy.pdf (accessed 15 October 2018)

Semakula, J. and Kashaka, U. (2017) 'Youth Loans: 80 in Trouble', New Vision, 5 February, https://archives.visiongroup.co.ug/nationalnews/35715-youth-loans-80-in-trouble (accessed 1 July 2017)

UBOS (2017) 2017 National Governance, Peace and Security (NGPS) Survey, Kampala: Uganda Bureau of Statistics, www.ubos.org/wp-content/ uploads/publications/08_201807_2018Governance_Peace_and_ Security_2017_PPTPresentation.pdf (accessed 15 October 2018)

UBOS (2015) 2015 Statistical Abstract, Kampala: Uganda Bureau of Statistics, www.ubos.org/wp-content/uploads/ publications/03_2018Statistical_Abstract_2015.pdf (accessed 15 October 2018)

Ukachukwu, N.A. (2014) 'Assessment of the Private Sectors' Contributions to Youth Empowerment among Youths in Rivers State, Nigeria', Singaporean fournal of Business Economics and Management Studies 2.6: 20-26

Vision Reporter (2018) 'OPM to Coordinate Vision 2040', New Vision, 10 April, www.newvision.co.ug/new_vision/news/1317058/opmcoordinate-vision-2040 (accessed 15 October 2018)

World Bank (2015) Toward Solutions for Youth Employment: A 2015 Baseline Report-Overview, Washington DC: World Bank, https://openknowledge.worldbank.org/handle/10986/23262 (accessed 15 October 2018) 